\title{
Rapid and Simple Detection of Trichosporon asahii by Optimized Colony PCR
}

\author{
Dequan Zhang $\mathbb{D}^{1,2}$ Xuelian Lu, ${ }^{3}$ Yong Liao, ${ }^{2}$ Zhikuan Xia, ${ }^{2}$ Zhuoying Peng, \\ Xin Yang, ${ }^{2}$ and Rongya Yang $\mathbb{1}^{2}$ \\ ${ }^{1}$ Army Medical University (Third Military Medical University), Chongqing 400038, China \\ ${ }^{2}$ The Military Institute of Injury and Reparation, The Seventh Medical Center of PLA General Hospital, Beijing 100700, China \\ ${ }^{3}$ Department of Dermatology, Beijing Anzhen Hospital, Capital Medical University, Beijing 100021, China
}

Correspondence should be addressed to Rongya Yang; yangrya@sina.com

Received 21 February 2019; Accepted 23 April 2019; Published 14 May 2019

Academic Editor: Roberto Amerigo Papini

Copyright (C) 2019 Dequan Zhang et al. This is an open access article distributed under the Creative Commons Attribution License, which permits unrestricted use, distribution, and reproduction in any medium, provided the original work is properly cited.

\begin{abstract}
Trichosporon asahii is the major pathogen causing invasive trichosporonosis. Conventional methods of its detection are timeconsuming or costly and often require complex DNA extraction and purification steps, which hinders rapid clinical diagnosis. In this study, we evaluated colony PCR, which directly uses colonies or trace clinical samples as the template for amplification, for rapid detection of T. asahii infection. Four methods, namely, direct colony, freeze-thaw, glass beads, and enzymolysis, were compared to select the best DNA extraction strategy. We subsequently designed and screened species-specific primers targeting the intergenic spacer 1 (IGS1) of the ribosomal DNA of T. asahii and used them to detect mock infection clinical samples. The species-specific colony PCR based on glass beads proved advantageous, with short procedure time (154.8 $\pm 0.6 \mathrm{~min}$ ), good sensitivity (detection limit, $10^{2} \mathrm{CFU} / \mathrm{mL}$ ), and specificity for T. asahii, indicating that this method can be used for the rapid and simple identification of clinical samples of T. asahii infection.
\end{abstract}

\section{Introduction}

Species of the Trichosporon genus exists widely in nature; the genus comprises 51 species, of which 16 are the pathogenic to humans. Following the genus Candida, Trichosporon is the most common pathogen among invasive yeast infections in patients with malignant hematological diseases [1]. T. asahii is the most common pathogen among Trichosporon infections and can cause invasive fatal trichosporonosis, especially in immunocompromised hosts, such as individuals suffering from neutropenia, organ transplantation, hematologic malignancies, extensive burns, or AIDS[2].

The identification of T. asahii and diagnosis of infection with the pathogen often involves biochemical methods, conventional or real-time quantitative PCR, and massspectrometric methods. These are based on pathological biopsy specimens and fungal culture. Traditional biochemical methods are currently the most common approach for identification of T. asahii infection. However, this method depends on the isolation and purification of the isolate, and it is difficult to differentiate $T$. asahii strains from other closely related Trichosporon species [3,4]. On the other hand, Matrix-Assisted Laser Desorption Ionization-Time of Flight Mass Spectrometry (MALDI-TOF MS) has already been applied for the identification of T. asahii [5]. However, only limited standard maps of the genus Trichosporon could be found in the original database, which made MALDITOF MS hard to be effectively and accurately applied for the identification of Trichosporon spp. Encouragingly, Kolecka and colleagues improved the accuracy and reliability of Trichosporon spp identification by extending reference maps of Trichosporon spp in MALDI-TOF database [6, 7]. Even so, this technology has limited application to pure cultures and the high cost of the equipment has limited its extensive clinical application to the hospital laboratories in developing countries.

The current fungal PCR amplification process is timeconsuming and often requires traditional cell wall-breaking 
methods to extract DNA. It is difficult to obtain high quality DNA, especially when the fungal burden of the specimen is low, thus extremely limiting its application in clinical diagnosis. All of the above limitations have hindered the use of molecular identification and the application of PCR technology to clinical samples of T. asahii infection. While we have previously adapted loop-mediated isothermal amplification (LAMP) for identification of T. asahii [8], there is still no low-cost molecular method for T. asahii identification available for all levels of medical institutions worldwide, especially in developing countries [9].

In 1989, Gussow and Clackon first successfully applied the colony PCR method for the diagnosis of bacterial infection [10]. Because the bacterial cell wall is thin and weak, simple mechanical effects and high temperature are sufficient for their lysis and to release their DNA. There have also been reports on the application of colony PCR for the detection of fungi, but the quality of the resulting products and the length of the procedures varied greatly [11-13]. We hypothesized that the varied results of colony PCR for molecular detection were due to variations in the efficiency of disrupting the fungal cell wall and that colony PCR can still be applied for the detection of fungi, provided the number of DNA copies is sufficient, following improvements in the efficiency of cell wall-breaking methods.

The internal transcriber spacer (ITS) region is highly homologous among species of the genus Trichosporon, leading to the poor performance of molecular identification of $T$. asahii and difficulty in distinguishing it from closely related species. Thus, a region that has greater divergence among Trichosporon species is required for successful identification: namely, the intergenic spacer (IGS) shows greater genetic diversity than ITS in Trichosporon. Therefore, IGS, especially IGS1, has become the current gold-standard for accurate Trichosporon spp. identification [14].

Given the above background information and due to the lack of a specific, highly sensitive, rapid, and simple T. asahii identification method, in this study, we aimed to develop a colony PCR strategy that would directly identify fungal elements representing T. asahii in clinical samples. This method may help in the early detection and rapid diagnosis of T. asahii infections and facilitate appropriate treatment for patients.

\section{Materials and Methods}

2.1. Strains and Culture. We used 15 Trichosporon asahii strains and 15 other Trichosporon strains, 28 nonTrichosporon fungal strains, and 9 bacterial strains (Table 1), to evaluate the sensitivity, positive rate, and primer specificity of the colony PCR strategy. Before the experiment, all strains were inoculated in potato dextrose agar or Luria-Bertani medium at $30-37^{\circ} \mathrm{C}$ for $48-72 \mathrm{~h}$.

2.2. Suspension Preparation. To acquire a decimal concentration gradient of suspensions $\left(10^{7}, 10^{6}, 10^{5}, 10^{4}, 10^{3}, 10^{2}\right.$, and $10^{1}$ $\mathrm{CFU} / \mathrm{mL}$ ), the suspension of $3.0 \times 10^{7} \mathrm{CFU} / \mathrm{mL}$ was diluted 10 -fold continuously. To confirm the concentration of spores,
$20 \mu \mathrm{L}$ of the suspension with a concentration of $10^{3} \mathrm{CFU} / \mathrm{mL}$ was subcultured onto potato dextrose agar. The mean colony count on each plate was 45-75 CFU after $48 \mathrm{~h}$ of incubation.

2.3. DNA Extraction Methods. For the direct colony method, $1 \mu \mathrm{L}$ of suspension was used directly as the template. For the glass bead method, beads (400-600 $\mu \mathrm{m}$; Sigma-Aldrich, St. Louis, MO, USA) were added to $400 \mu \mathrm{L}$ of suspension, and the mixture was vortexed using a FastPrep ${ }^{\circledR}-24$ Instrument (MP Biomedicals, USA) at a speed of $4 \mathrm{~m} / \mathrm{s}$ for $20 \mathrm{~s}$. After resting shortly, $1 \mu \mathrm{L}$ of supernatant was used as the template. For the freeze-thaw method, $400 \mu \mathrm{L}$ of the suspension was boiled at $100^{\circ} \mathrm{C}$ for $5 \mathrm{~min}$, frozen at $-80^{\circ} \mathrm{C}$ for $15 \mathrm{~min}$, and then boiled at $100^{\circ} \mathrm{C}$ for $10 \mathrm{~min}$. One microliter of the supernatant was used as the template. For the enzymolysis method, Snailase (Sigma-Aldrich) was added to $400 \mu \mathrm{L}$ of the suspension. The mixture was incubated at $37^{\circ} \mathrm{C}$ for 1 $h$, and $1 \mu \mathrm{L}$ of suspension was used as the template. For the traditional DNA extraction method, DNA was extracted from T. asahii per the CBS protocol "Extraction of ribosomal DNA according to Möller (modified).”

2.4. Primers and Design. In order to evaluate the efficiency of the DNA extraction methods, we chose the panfungal primers 26SF and 5SR to amplify partial 26S rDNA, IGS1, and partial $5 \mathrm{~S}$ rDNA. Four species-specific primer pairs derived from the IGS1 region of ribosomal DNA (rDNA) were designed for T. asahii identification using Oligo software (v. 7.60). Target sequences were retrieved from the NCBI website (https://blast.ncbi.nlm.nih.gov/Blast.cgi). All primers were then synthesized by Sangon Biotech (Shanghai, China). The sequence of each primer is shown in Table 3.

2.5. PCR Conditions. PCR was performed in a total reaction volume of $25 \mu \mathrm{L}$, containing $3 \mu \mathrm{L}$ of $10 \times$ buffer, $0.2 \mathrm{mM}$ dNTPs, $0.6 \mathrm{mM} \mathrm{MgCl}_{2}, 0.4 \mu \mathrm{M}$ of each primer, $1 \mathrm{U}$ Taq DNA polymerase, and $1 \mu \mathrm{L}$ of DNA template. Thermal cycling consisted of $5 \mathrm{~min}$ at $94^{\circ} \mathrm{C}$ for initial denaturation, followed by 30 cycles of denaturation at $94^{\circ} \mathrm{C}$ for $45 \mathrm{~s}$, annealing at $53^{\circ} \mathrm{C}$ for $45 \mathrm{~s}$, and extension at $72^{\circ} \mathrm{C}$ for $75 \mathrm{~s}$, with a final extension step at $72^{\circ} \mathrm{C}$ for $7 \mathrm{~min}$. The PCR products were examined by electrophoresis on $1.5 \% \mathrm{w} / \mathrm{v}$ agarose gels.

2.6. Sensitivity Detection. To determine the sensitivity of each method, the serial dilutions of T. asahii CBS2479 were subjected to the different DNA extraction methods.

2.7. Positive Rate of Trace Detection. To evaluate the positive rate of trace detection of each method, suspensions of $15 \mathrm{~T}$. asahii strains, at a concentration of $10^{3} \mathrm{CFU} / \mathrm{mL}$, were used.

2.8. Direct Detection of T. asahii from Clinical Samples Mimicking Infection. Clinical samples including whole blood, bronchoalveolar lavage fluid (BALF), and urine were collected from patients at our hospital. Suspensions of $T$. asahii CBS2479 were mixed with the clinical samples to a concentration of $10^{7} \mathrm{CFU} / \mathrm{mL}$, and the mixtures were diluted 10 -fold using the respective samples. Whole blood samples 
TABLE 1: Strains used in this study and the specificity evaluation of species-specific primers for detecting T. asahii.

\begin{tabular}{|c|c|c|c|c|c|}
\hline \multirow{2}{*}{ Organism } & \multirow{2}{*}{ Strain } & \multicolumn{4}{|c|}{ Specificity detection } \\
\hline & & TA1 & TA2 & TA3 & TA4 \\
\hline Trichosporon asahii & BZP7001 & + & + & + & + \\
\hline Trichosporon asahii & BZP7002 & + & + & + & + \\
\hline Trichosporon asahii & BZP7003 & + & + & + & + \\
\hline Trichosporon asahii & BZP7004 & + & + & + & + \\
\hline Trichosporon asahii & BZP7005 & + & + & + & + \\
\hline Trichosporon asahii & BZP9001 & + & + & + & + \\
\hline Trichosporon asahii & BZP9002 & + & + & + & + \\
\hline Trichosporon asahii & CBS2479 & + & + & + & + \\
\hline Trichosporon asahii & BZP4848 & + & + & + & + \\
\hline Trichosporon asahii & BZP6108 & + & + & + & + \\
\hline Trichosporon asahii & BZP6198 & + & + & + & + \\
\hline Trichosporon asahii & BZP6674 & + & + & + & + \\
\hline Trichosporon asahii & CBS7137 & + & + & + & + \\
\hline Trichosporon asahii & CBS8520 & + & + & + & + \\
\hline Trichosporon asahii & CBS8904 & + & + & + & + \\
\hline Trichosporon debeurumanianum & CBS1896 & - & - & - & - \\
\hline Trichosporon dermatis & CBS2043 & - & - & - & - \\
\hline Trichosporon cutaneum & CBS2466 & - & - & - & - \\
\hline Trichosporon asteroides & CBS2481 & - & + & + & - \\
\hline Trichosporon coremiiforme & CBS2482 & - & + & + & - \\
\hline Trichosporon faecale & CBS4828 & - & + & + & - \\
\hline Trichosporon inkin & CBS5585 & - & - & - & - \\
\hline Trichosporon jirovecii & CBS6864 & - & - & - & - \\
\hline Trichosporon ovoides & CBS7556 & - & - & - & - \\
\hline Trichosporon mucoides & CBS7625 & - & - & - & - \\
\hline Trichosporon montevideense & CBS8261 & - & + & + & - \\
\hline Trichosporon domesticum & CBS8280 & - & - & - & - \\
\hline Trichosporon japonicum & CBS8641 & - & + & - & - \\
\hline Trichosporon lactis & CBS9051 & - & - & - & - \\
\hline Trichosporon dohaense & CBS10761 & - & - & - & - \\
\hline Candida dubliniensis & $\mathrm{CMCC}(\mathrm{F}) \mathrm{C} 8 \mathrm{f}$ & - & - & - & - \\
\hline Candida tropicalis & $\mathrm{CMCC}(\mathrm{F}) \mathrm{C} 2 \mathrm{f}$ & - & - & - & - \\
\hline Candida parapsilosis & $\mathrm{CMCC}(\mathrm{F}) \mathrm{C} 4 \mathrm{f}$ & - & - & - & - \\
\hline Candida glabrata & CMCC(F)T10a & - & - & - & - \\
\hline Candida metapsilosis & $\mathrm{CMCC}(\mathrm{F}) \mathrm{C} 4 \mathrm{k}$ & - & - & - & - \\
\hline Candida albicans & ATCC90028 & - & - & - & - \\
\hline Cryptococcus neoformans & $\mathrm{CMCC}(\mathrm{F}) \mathrm{D} 2 \mathrm{a}$ & - & - & - & - \\
\hline Cryptococcus gattii & $\mathrm{CMCC}(\mathrm{F}) \mathrm{D} 2 \mathrm{e}$ & - & - & + & - \\
\hline Trichophyton rubrum & CMCC(F)T1h & - & - & - & - \\
\hline Trichophyton violaceum & BZP1501 & - & - & - & - \\
\hline Trichophyton mentagrophytes & CMCC(F)T5e & - & - & - & - \\
\hline Malassezia furfur & $\mathrm{CMCC}(\mathrm{F}) \mathrm{T} 17 \mathrm{a}$ & - & - & - & - \\
\hline Malassezia sympodialis & $\operatorname{CMCC}(\mathrm{F}) \mathrm{T} 14 \mathrm{a}$ & - & - & - & - \\
\hline Sporothrix schenkii & CMCC(F)Dla & - & - & - & - \\
\hline Microsporum gypseum & $\mathrm{CMCC}(\mathrm{F}) \mathrm{M} 2 \mathrm{~b}$ & - & - & - & - \\
\hline Microsporum canis & $\mathrm{CMCC}(\mathrm{F}) \mathrm{M} 3 \mathrm{~h}$ & + & - & - & - \\
\hline Aspergillus versicolor & CMCC(F)A5c & - & - & - & - \\
\hline Aspergillus fumigatus & CMCC(F)Alg & + & - & - & - \\
\hline Aspergillus niger & $\mathrm{CMCC}(\mathrm{F}) \mathrm{A} 3 \mathrm{a}$ & - & - & - & - \\
\hline Aspergillus nidulans & $\mathrm{CMCC}(\mathrm{F}) \mathrm{A} 7 \mathrm{c}$ & - & - & - & - \\
\hline
\end{tabular}


TABLE 1: Continued.

\begin{tabular}{|c|c|c|c|c|c|}
\hline \multirow{2}{*}{ Organism } & \multirow{2}{*}{ Strain } & \multicolumn{4}{|c|}{ Specificity detection } \\
\hline & & TA1 & TA2 & TA3 & TA4 \\
\hline Fonsecaea pedrosoi & CMCC(F)D6j & + & - & - & - \\
\hline Phialophora verrucosa & $\mathrm{CMCC}(\mathrm{F}) \mathrm{D} 8 \mathrm{i}$ & - & - & - & - \\
\hline Scedosporium apiospermum & CMCC(F)D13f & - & - & - & - \\
\hline Penicillium marneffei & $\mathrm{CMCC}(\mathrm{F}) \mathrm{B} 33 \mathrm{a}$ & - & - & - & - \\
\hline Rhizopus oryzae & $\mathrm{CMCC}(\mathrm{F}) \mathrm{B} 81 \mathrm{c}$ & - & - & - & - \\
\hline Mucor circinelloides & $\mathrm{CMCC}(\mathrm{F}) \mathrm{B} 57 \mathrm{a}$ & - & - & - & - \\
\hline Fusarium oxysporum & $\mathrm{CMCC}(\mathrm{F}) \mathrm{B} 38 \mathrm{c}$ & - & - & - & - \\
\hline Absidia Corymbifera & $\mathrm{CMCC}(\mathrm{F}) \mathrm{B} 69 \mathrm{f}$ & - & - & - & - \\
\hline Staphylococcus aureus & Clinical isolates & - & - & - & - \\
\hline Staphylococcus epidermidis & Clinical isolates & - & - & - & - \\
\hline Streptococcus pneumoniae & Clinical isolates & - & - & - & - \\
\hline Streptococcus pyogenes & Clinical isolates & - & - & - & - \\
\hline Klebsiella pneumonia & Clinical isolates & - & - & - & - \\
\hline Escherichia coli & Clinical isolates & - & - & - & - \\
\hline Acinetobacter baumannii & Clinical isolates & - & - & - & - \\
\hline Enterococcus faecium & Clinical isolates & - & - & - & - \\
\hline Serratia odorifera & Clinical isolates & - & - & - & - \\
\hline Healthy human DNA & & - & - & - & - \\
\hline Negative control & & - & - & - & - \\
\hline
\end{tabular}

ATCC: American type culture collection, Rockville, MD, USA; CBS: Centraalbureau voor Schimmelcultures, Baarn, The Netherlands; CMCC: China Medical Culture Collection, Nanjing, China; BZP: The Military Institute of Injury and Reparation, China.

were lysed with Red Blood Cell (RBC) Lysis Buffer (Thermo Fisher Scientific, Waltham, MA, USA). All prepared samples were pretreated with glass beads and then directly used as templates for the PCR reaction.

2.9. Controls. A number of precautions were undertaken to control the occurrence of false-positive results. No-templates were processed together with the specimens tested. All experiments were performed in triplicate.

\section{Results}

3.1. Sensitivity of Colony PCR. The analytical sensitivity was determined by 10 -fold serial dilutions of the T. asahii suspension. The minimal detection concentration of the glass bead and freeze-thaw methods was approximately $10^{2}$ $\mathrm{CFU} / \mathrm{mL}$ (Figures 1(a), lane 6, and 1(b), lane 6). The direct colony and enzymolysis methods presented the sensitivity of $10^{3} \mathrm{CFU} / \mathrm{mL}$ (Figures 1(c), lane 5, and 1(d), lane 5). The minimal detection concentration of the traditional DNA extraction method was also $10^{3} \mathrm{CFU} / \mathrm{mL}$ (Figure 1(e), lane 5). Similar results were obtained when the assay was repeated, demonstrating the reproducibility of the test.

3.2. Positive Rate of Trace Detection of Colony PCR. In light of the above results, we chose the concentration of $10^{3} \mathrm{CFU} / \mathrm{mL}$ to evaluate the positive rate of trace detection of colony PCR. Fifteen strains of T. asahii yielded positive results by glass beads method (Figure 2(a)), presenting a positive rate of $100 \%$. Eleven of the 15 strains yielded positive results by the freeze-thaw method (Figure 2(b)) and direct colony method (Figure 2(c)); i.e., the positive rate was $73.3 \%$. The positive rate of the enzymolysis method was $93.3 \%$, with 14 out of 15 strains being positive (Figure 2(d)). Only 8 of the 15 strains were shown positive by electrophoresis when the traditional DNA extraction method was used, i.e., positive rate was $53.3 \%$ (Figure 2(e)).

3.3. Procedure Duration. The duration of colony PCR was evaluated: it was significantly lower in the direct colony and glass bead groups, with $151 \pm 0.3 \mathrm{~min}$ and $154.8 \pm 0.6 \mathrm{~min}$, respectively, compared to the freeze-thaw, enzymolysis, and traditional DNA extraction groups, which took $182.7 \pm 1.5$ $\mathrm{min}, 210.6 \pm 0.4 \mathrm{~min}$, and $445.4 \pm 7.9 \mathrm{~min}$, respectively (Table 2).

3.4. Specificity Test. Reference strains of species closely related to T. asahii, other fungal strains, and bacterial strains or human DNA extracted from healthy subjects or controls lacking genomic DNA yielded negative (no amplification) results when using the primers TA4F and TA4R. The other primers did not meet the specificity requirements (Table 1). Consequently, TA4F and TA4R, which showed perfect specificity, were selected for subsequent optimization of colony PCR.

3.5. Analysis of Infectious Samples. Colony PCR was performed on infectious samples. All of the samples tested positive, whereas the control group tested negative (Table 4). The colony PCR exhibited high sensitivity to whole blood, 


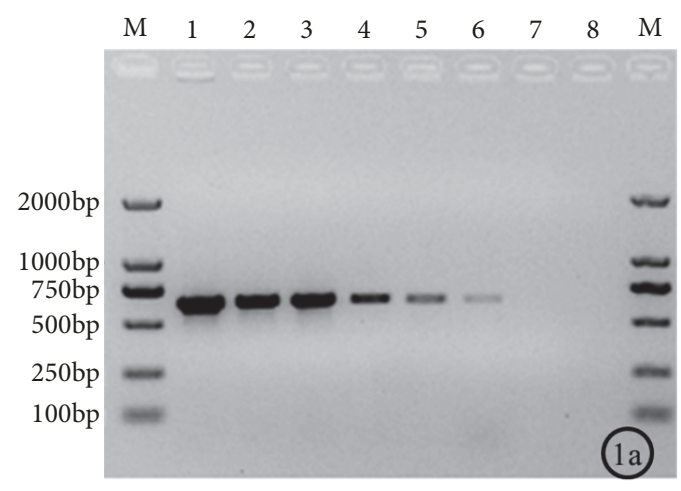

(a)

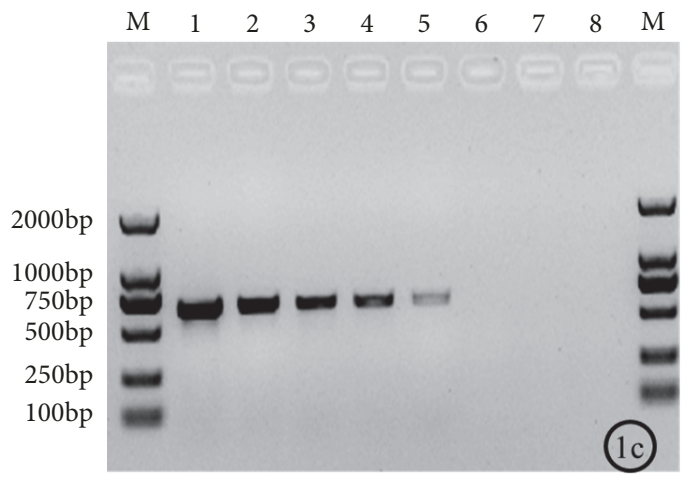

(c)

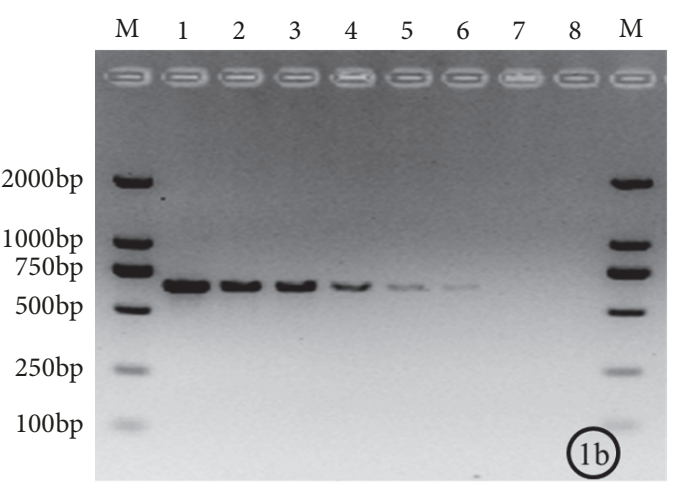

(b)

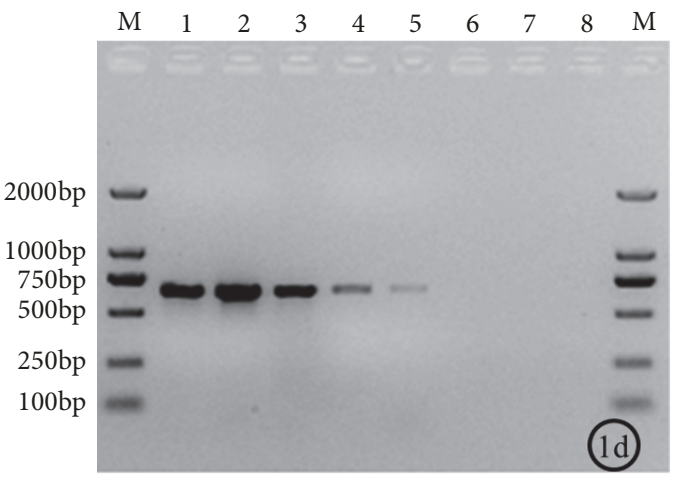

(d)

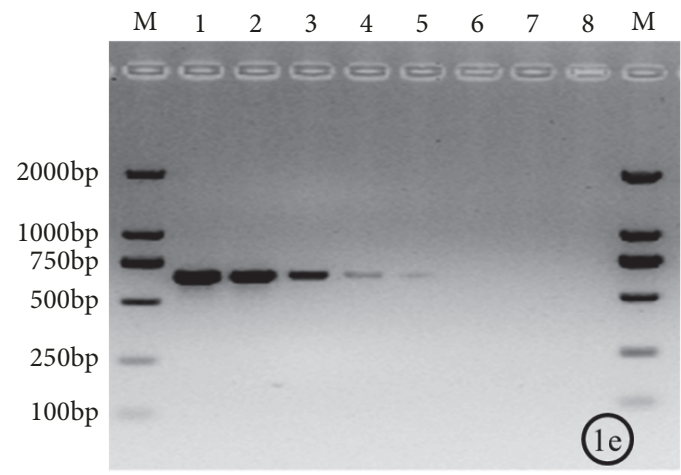

(e)

FIgURE 1: The sensitivity of colony PCR detection based on different methods. M: DNA Ladder; 1-7: Suspension of the type strain of T. asahii CBS2479, Concentration followed by $10^{7}, 10^{6}, 10^{5}, 10^{4}, 10^{3}, 10^{2}, 10^{1} \mathrm{CFU} / \mathrm{mL} ; 8$ : Negative control; 1(a): glass beads; 1(b): freeze-thawing; 1(c): direct colony; 1(d): enzymolysis; 1(e): traditional DNA extraction.

TABLE 2: Sensitivities, positive rate of trace detection, and procedure duration of different colony PCR methods for detecting T. asahii.

\begin{tabular}{|c|c|c|c|c|c|c|}
\hline \multirow{2}{*}{ Methods } & \multirow{2}{*}{ Sensitivity } & \multirow{2}{*}{ Positive rate of trace detection } & \multicolumn{4}{|c|}{ Procedure duration } \\
\hline & & & Pretreatment & PCR & Electrophoresis & Total \\
\hline glass beads & $10^{2} \mathrm{CFU} / \mathrm{mL}$ & $100 \%(15 / 15)$ & $4.8 \pm 0.6 \mathrm{~min}$ & & & $154.8 \pm 0.6 \mathrm{~min}$ \\
\hline freeze-thawing & $10^{2} \mathrm{CFU} / \mathrm{mL}$ & $73.33 \%(11 / 15)$ & $32.7 \pm 1.5 \mathrm{~min}$ & & & $182.7 \pm 1.5 \mathrm{~min}$ \\
\hline direct colony & $10^{3} \mathrm{CFU} / \mathrm{mL}$ & $73.33 \%(11 / 15)$ & $1 \pm 0.3 \mathrm{~min}$ & $100 \mathrm{~min}$ & $50 \mathrm{~min}$ & $151 \pm 0.3 \mathrm{~min}$ \\
\hline enzymolysis & $10^{3} \mathrm{CFU} / \mathrm{mL}$ & $93.33 \%(14 / 15)$ & $60.6 \pm 0.4 \mathrm{~min}$ & & & $210.6 \pm 0.4 \mathrm{~min}$ \\
\hline traditional DNA extraction & $10^{3} \mathrm{CFU} / \mathrm{mL}$ & $53.33 \%(8 / 15)$ & $295.4 \pm 7.9 \mathrm{~min}$ & & & $445.4 \pm 7.9 \mathrm{~min}$ \\
\hline
\end{tabular}




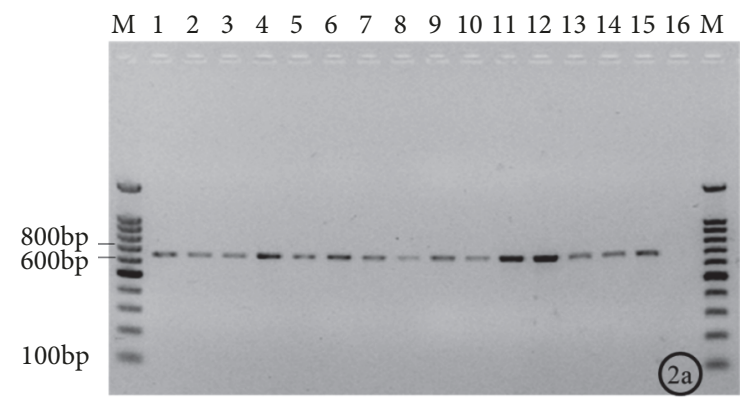

(a)

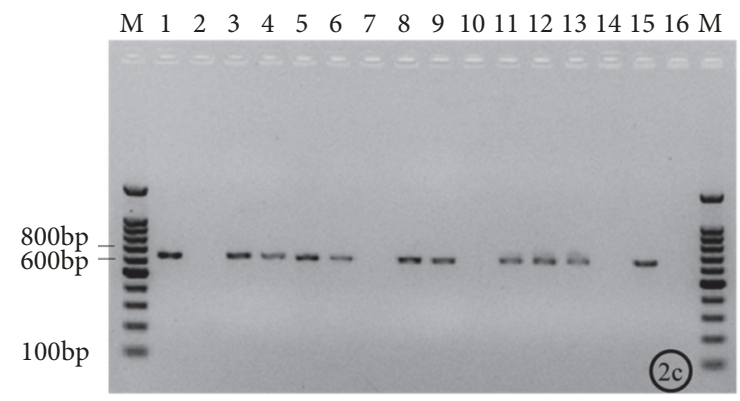

(c)

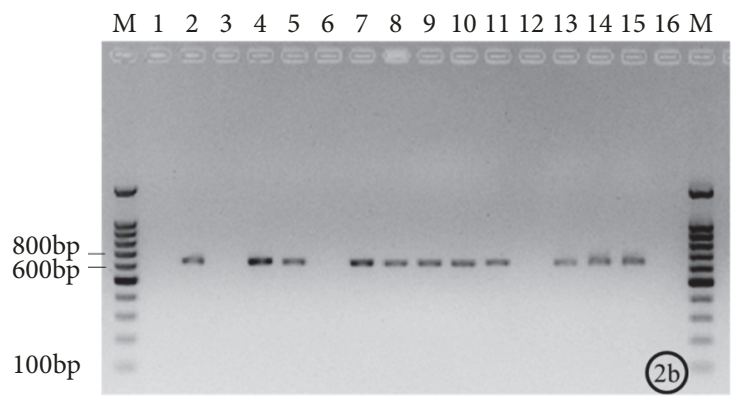

(b)

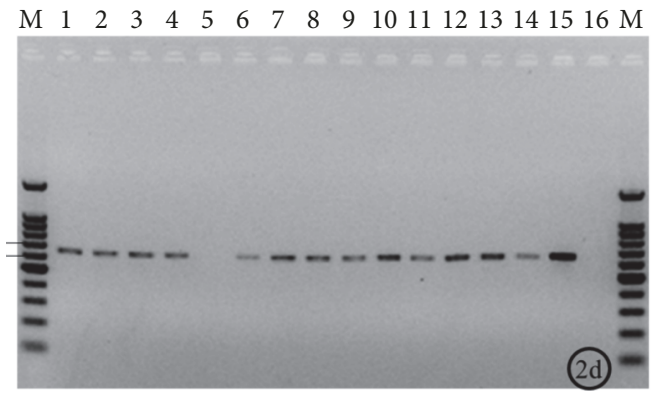

(d)

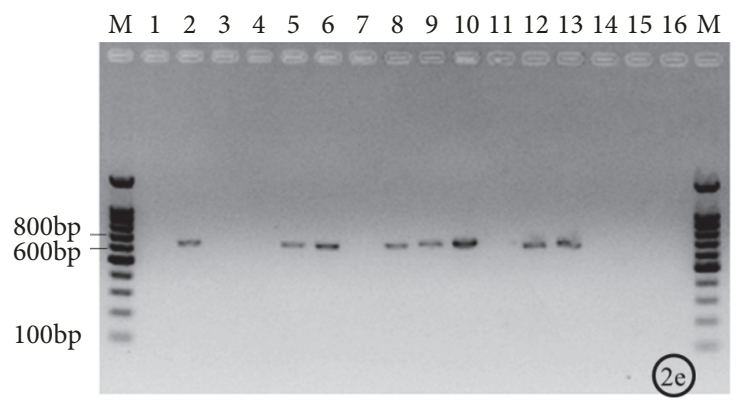

(e)

FIGURE 2: The positive rate of trace detection of colony PCR trace detection based on different methods for 15 isolates of Trichosporon asahii. M: DNA Ladder; 1: BZP7001; 2: BZP7002; 3: BZP7003; 4: BZP7004; 5: BZP7005; 6: BZP9001; 7: BZP9002; 8: CBS2479; 9: BZP4848; 10: BZP6108; 11: BZP6198; 12: BZP6674; 13: CBS7137; 14: CBS8520; 15: CBS8904; 16: Negative control; 2(a): glass beads; 2(b): freeze-thawing; 2(c): direct colony; 2(d): enzymolysis; 2(e): traditional DNA extraction.

TABle 3: Primers used in this study.

\begin{tabular}{lc}
\hline $\begin{array}{c}\text { Primer } \\
\text { Name }\end{array}$ & Sequence $\left(5^{\prime}-3^{\prime}\right)$ \\
\hline $26 S F$ & ATCCTTTGCAGACGACTTGA \\
5 SR & AGCTTGACTTCGCAGATCGG \\
TA1F & GTGAATCAAGAACGAAGTATAAGGG \\
TA1R & AGACCTCAGCCTCTGACAGC \\
TA2F & CCTTTTGGACTCTCTATGATTGG \\
TA2R & CCATCCTTCCAACTTGTAGCTT \\
TA3F & TTGGACTCTCTATGATTGGCA \\
TA3R & TCTAGTCCTCAACCGCCCT \\
TA4F & GCGACCTCAGCATCTTAATCA \\
TA4R & CTCTGAGGCCTTGCTCCTGT \\
\hline
\end{tabular}

BALF, and urine samples mimicking infection that reach up to $10^{2} \mathrm{CFU} / \mathrm{mL}$.

\section{Discussion}

T. asahii is the most commonly isolated species from patients with invasive trichosporonosis [9], and establishing a fast and effective molecular detection method would be helpful in the early clinical diagnosis of this infection. T. asahii has become the predominant species involved in systemic mycosis. The emergence of less common, but medically important opportunistic fungal pathogens has contributed to an increase in the rate of morbidity and mortality [15]. Due to the low immune status, multiple pathogenic organisms may coexist in the same patient. To eliminate the interference of other pathogenic organisms, high specificity of the identification method is particularly important. Colony 
TABLE 4: Results of colony PCR in clinical samples mimicking infection.

\begin{tabular}{lcccc}
\hline \multirow{2}{*}{ Sample type } & \multicolumn{2}{c}{ Infectious samples } & \multicolumn{2}{c}{ NCR results } \\
& No. of samples & No. positive (\%) & No. of samples & No. positive (\%) \\
\hline Human, whole blood & 10 & $10(100)$ & 10 & $0(0)$ \\
Human, bronchoalveolar lavage & 10 & $10(100)$ & 10 & $0(0)$ \\
Human, urine & 10 & $10(100)$ & 10 & $0(0)$ \\
\hline
\end{tabular}

PCR is widely used in various fields of microbiological science, including Escherichia coli, Bacillus subtilis, Bacillus coagulans, Pichia pastoris, Candida, and Aspergillus detection $[11,16,17]$, and has the potential to be used as a simple detection assay on account of its simplicity, robustness, and low cost. Unfortunately, the application of colony PCR for the detection of T. asahii has not yet been researched due to the difficulty in cell-wall destruction during sample treatment. In this study, we set up and evaluated the performance of a colony PCR assay for the detection of T. asahii in culture and mimicking clinical samples.

Due to the cell-wall differences among the species, the quality of amplicons obtained by colony PCR differs in different pathogen studies. High quality and purity of extracted DNA is the foundation of reliable colony PCR. Therefore, the efficiency of cell wall break-down methods needs to be improved. The previous applications of colony PCR were based on pure colony culture, requiring an additional time of 24-48 hours or more, which greatly undermined the rapidity of the colony PCR technology $[11,13]$. The above two problems have created an insurmountable gap between the colony PCR technology and the rapid clinical detection of pathogenic fungi. Only by bridging this gap can the advantages of this technology be truly applied in the clinical setting. To this end, our study has three highlight points: (1) analysis of the rapid and convenient release method of fungal DNA, and preliminary establishment of a colony PCR detection system with high sensitivity and simple operation methods; (2) development of the T. asahii-specific colony PCR detection method through design, screening, and specificity determination of species-specific primers, so that this method can be used to detect not only T. asahii but also other pathogenic fungi by simply changing the genus- or species-specific primers; (3) evaluation of the applicability of the T. asahiispecific colony PCR detection method to clinical samples.

In this study, we compared the efficiency of various methods for preliminary DNA extraction. The results showed that the sensitivity and positive rate of the glass beads method were $3 \times 10^{2} \mathrm{CFU} / \mathrm{mL}$ and $100 \%$, respectively, with a markedly low time consumption of $154.8 \pm 0.6 \mathrm{~min}$. One microliter of the suspension with a concentration of $3 \times 10^{2} \mathrm{CFU} / \mathrm{mL}$ contained approximately $3 \times 10^{-1}$ spores, which were detectable by PCR considering that each spore contains multiple copies of rDNA. In fact, according to a study, there are about 100-150 copies of rDNA genes of the yeast cell located in one chromosome of Saccharomyces cerevisiae $[18,19]$. Therefore, $1 \mu \mathrm{L}$ of the suspension contained estimated $30-45$ copies. On the other hand, the glass beads method has a high cell wall-broken efficiency, and the multiple copies of rDNA and high wall-broken efficiency yielded an adequate amount of DNA for amplification. Meanwhile, false-positive results can be avoided by aseptic conditions and by minimizing the length of DNA extraction to $20 \mathrm{~s}$. These advantages are not offered by the other three methods in this study. The glass beads method can overcome the disadvantages of the previous colony PCR method in practical applications. Therefore, we decided to use the glass beads method as the colony PCR pretreatment strategy and initially established a highly sensitive, convenient, and easily operable colony PCR system.

ITS has been used to molecularly identify the microorganism, but the IGS1 region is considered more suitable for accurate Trichosporon species identification due to higher discriminatory power [20-22]. To accurately identify T. asahii strains to the species level, we designed 4 pairs of speciesspecific primers based on the IGS1 region of rDNA and successfully obtained the primers TA4F and TA4R that had satisfactory specificity. The primers TA4F and TA4R showed high specificity for IGS1 of T. asahii and did not amplify DNA of other common pathogenic fungi and bacteria. This method can detect various T. asahii strains using only colony PCR within $3 \mathrm{~h}$, without fungal culture, DNA extraction, and sequencing for species identification. So far, we successfully established a T. asahii-specific detection method based on colony PCR, which is of great significance for the current situation regarding clinical T. asahii infection and the urgent requirement for a novel detection method.

PCR is often used to detect DNA extracted from pure culture colonies derived from infected samples, but seldom used to directly detect pathogens in clinical samples. In order to determine whether the complex components in clinical infection samples would interfere with the amplification efficiency of the PCR reaction and further observe the detection limit of colony PCR for clinical samples infected with $T$. asahii, we chose to use simulated clinical samples in this study. Considering that $T$. asahii seems to be common species isolated from the blood, BALF, and urine of hospitalized patients $[9,20,23,24]$, we used the species-specific colony PCR to investigate whole blood, BALF, and urine samples mimicking infection. The assay yielded positive results in whole blood, BALF, and urine mimicking human infection, with a high sensitivity of $10^{2} \mathrm{CFU} / \mathrm{mL}$. These factors reinforce the need for methods that provide rapid and accurate identification of $T$. asahii from easily obtainable clinical samples, and the trace detection sensitivity of species-specific colony PCR fully meets these requirements. 
Previous studies on the application of nested PCR in the detection of T. asahii in clinical samples reported some shortcomings, such as the need to sequence the amplification products to identify the pathomycete [25], or the selection of the ITS region with small interspecies differences as the amplification region [26]. Although several studies have reported the successful detection of T. asahii in different clinical samples by real-time quantitative PCR, the currently recognized IGS1 region was not selected for primer designing $[27,28]$. This could lead to interspecies misinterpretation, if Trichosporon species are identified through the non-IGS1 region. There have also been reports on the design of speciesspecific primers for real-time quantitative PCR based on the IGS1 region for the detection of T. asahii in whole blood samples. However, the procedure required extraction of DNA from blood samples for amplification, which increased the total time of detection [29]. Our previous study on the detection of T. asahii using LAMP technology also showed requirement for DNA extraction after obtaining pure culture, and the cost of this technology was much higher than that of PCR, both of which hindered the application of this technology in clinical practice [8]. The T. asahii-specific colony PCR method for direct detection of the infection in clinical samples, established in this study, can overcome the drawbacks of the nucleic acid amplification technology mentioned above, so as to meet the need for rapid detection of pathogens in clinical practice and facilitate early treatment strategies.

The T. asahii detection method established in this study proved to be efficient and easily operable. This method does not require the use of expensive equipment or special kits or reagents. It can be widely carried out in developing countries or low-level medical institutions. At the same time, the technology has broad expansibility: the specific detection of other pathomycete can be efficiently performed by simply replacing the genus- or species-specific primers. In order to further shorten the detection time, we plan to demonstrate the feasibility of real-time quantitative colony PCR in our next study.

\section{Conclusions}

In conclusion, our study found that species-specific colony PCR, preceded by glass bead DNA extraction, could be used for the identification of T. asahii. In comparison with conventional methods, it produces results in a shorter time (within $3 \mathrm{~h}$ ), requires less effort and resources, and is less expensive, rendering it suitable for diagnostic application. This methods applicability will enable medical institutions with poorer diagnostic capabilities to perform accurate diagnosis of $T$. asahii infection. At the same time, it can be extended to detect more pathogenic fungi and offer research scope to further shorten the detection time.

\section{Data Availability}

No data were used to support this study.

\section{Conflicts of Interest}

The authors declare that there are no conflicts of interest regarding the publication of this article.

\section{Acknowledgments}

We thank Qi Lihua (Microbiology Laboratory, The Seventh Medical Center of PLA General Hospital, China) for providing us with clinical isolates of bacteria. We especially thank Zhou Peng (Department of Biochemistry and Molecular Biology, Army Medical University, China) and Wang Ting (Center of Pharmaceutical Technology, Tsinghua University, China) for their technical advice on primers design. We would like to thank Editage (www.editage.com/) for English language editing. This study was funded by grants from National Natural Science Foundation of China (no. 81571972 and no. 81471928) and Beijing Nova Program (no. Z161100004916139).

\section{References}

[1] T. C. Chagas-Neto, G. M. Chaves, and A. L. Colombo, "Update on the genus Trichosporon," Mycopathologia, vol. 166, no. 3, pp. 121-132, 2008.

[2] M. H. Miceli, J. A. Díaz, and S. A. Lee, "Emerging opportunistic yeast infections," The Lancet Infectious Diseases, vol. 11, no. 2, pp. 142-151, 2011.

[3] G. E. Davies and C. R. Thornton, "Differentiation of the emerging human pathogens trichosporon asahii and trichosporon asteroides from other pathogenic yeasts and moulds by using species-specific monoclonal antibodies," PLOS ONE, vol. 9, no. 1, Article ID e84789, 2014.

[4] D. S. Y. de Figueiredo, J. N. de Almeida, A. L. Motta, D. M. Castro e Silva, M. W. Szeszs, and G. M. B. Del Negro, "Evaluation of VITEK 2 for discriminating trichosporon species: misidentification of trichosporon non-T. asahii," Diagnostic Microbiology and Infectious Disease, vol. 80, no. 1, pp. 59-61, 2014.

[5] S. Ilyas, A. Rehman, A. C. Varela, and D. Sheehan, "Redox proteomics changes in the fungal pathogen trichosporon asahii on arsenic exposure: Identification of protein responses to metal-induced oxidative stress in an environmentally-sampled isolate," PLoS ONE, vol. 9, no. 7, Article ID e102340, 2014.

[6] A. Kolecka, K. Khayhan, M. Groenewald et al., "Identification of medically relevant species of arthroconidial yeasts by use of matrix-assisted laser desorption ionization-time of flight mass spectrometry," Journal of Clinical Microbiology, vol. 51, no. 8, pp. 2491-2500, 2013.

[7] J. N. de Almeida Júnior, D. S. Y. Figueiredo, D. Toubas et al., "Usefulness of matrix-assisted laser desorption ionisationtime-of-flight mass spectrometry for identifying clinical Trichosporon isolates," Clinical Microbiology and Infection, vol. 20, no. 8, pp. 784-790, 2014.

[8] J. Zhou, Y. Liao, H. Li et al., "Development of a loopmediated isothermal amplification assay for rapid detection of Trichosporon asahii in experimental and clinical samples," BioMed Research International, vol. 2015, Article ID 732573, 9 pages, 2015.

[9] A. L. Colombo, A. C. B. Padovan, and G. M. Chaves, "Current knowledge of Trichosporon spp. and Trichosporonosis," Clinical Microbiology Reviews, vol. 24, no. 4, pp. 682-700, 2011. 
[10] D. Güssow and T. Clackson, "Direct clone characterization from plaques and colonies by the polymerase chain reaction," Nucleic Acids Research, vol. 17, no. 10, p. 4000, 1989.

[11] H. Packeiser, C. Lim, B. Balagurunathan, J. Wu, and H. Zhao, "An extremely simple and effective colony PCR procedure for bacteria, yeasts, and microalgae," Applied Biochemistry and Biotechnology, vol. 169, no. 2, pp. 695-700, 2013.

[12] C. M. J. Van Zeijl, E. H. M. Van De Kamp, P. J. Punt et al., "An improved colony-PCR method for filamentous fungi for amplification of pcr-fragments of several kilobases," Journal of Biotechnology, vol. 59, no. 3, pp. 221-224, 1997.

[13] X. Lin, F. Yang, Y. Zhou et al., "Highly-efficient colony PCR method for red yeasts and its application to identify mutations within two leucine auxotroph mutants," Yeast, vol. 29, no. 11, pp. 467-474, 2012.

[14] T. Sugita, M. Nakajima, R. Ikeda, T. Matsushima, and T. Shinoda, "Sequence analysis of the ribosomal DNA intergenic spacer 1 regions of Trichosporon species," Journal of Clinical Microbiology, vol. 40, no. 5, pp. 1826-1830, 2002.

[15] C. Girmenia, L. Pagano, B. Martino et al., "Invasive infections caused by trichosporon species and geotrichum capitatum in patients with hematological malignancies: a retrospective multicenter study from Italy and review of the literature," Journal of Clinical Microbiology, vol. 43, no. 4, pp. 1818-1828, 2005.

[16] M. Wan, J. N. Rosenberg, J. Faruq, M. J. Betenbaugh, and J. Xia, "An improved colony PCR procedure for genetic screening of Chlorella and related microalgae," Biotechnology Letters, vol. 33, no. 8, pp. 1615-1619, 2011.

[17] M. M. AlShahni, K. Makimura, T. Yamada et al., "Direct colony PCR of several medically important fungi using Ampdirect plus," Japanese Journal of Infectious Diseases, vol. 62, no. 2, pp. 164-167, 2009.

[18] T. D. Petes and D. Botstein, "Simple Mendelian inheritance of the reiterated ribosomal DNA of yeast," Proceedings of the National Acadamy of Sciences of the United States of America, vol. 74, no. 11, pp. 5091-5095, 1977.

[19] S. W. Stumpferl, S. E. Brand, J. C. Jiang et al., "Natural genetic variation in yeast longevity," Genome Research, vol. 22, no. 10, pp. 1963-1973, 2012.

[20] A. Kalkanci, T. Sugita, S. Arikan et al., "Molecular identification, genotyping, and drug susceptibility of the basidiomycetous yeast pathogen Trichosporon isolated from Turkish patients," Medical Mycology, vol. 48, no. 1, pp. 141-146, 2010.

[21] M. J. Espy, J. R. Uhl, L. M. Sloan et al., "Real-time PCR in clinical microbiology: applications for routine laboratory testing," Clinical Microbiology Reviews, vol. 19, pp. 165-256, 2006.

[22] N. Mekha, T. Sugita, R. Ikeda et al., "Genotyping and antifungal drug susceptibility of the pathogenic yeast Trichosporon asahii isolated from Thai patients," Mycopathologia, vol. 169, no. 1, pp. 67-70, 2010.

[23] A. M. Silvestre Junior, M. A. B. R. Miranda, and Z. P. de Camargo, "Trichosporon species isolated from the perigenital region, urine and catheters of a brazilian population," Brazilian Journal of Microbiology, vol. 41, no. 3, pp. 628-634, 2010.

[24] K. Unoura, Y. Miyazaki, Y. Sumi, M. Tamaoka, T. Sugita, and $\mathrm{N}$. Inase, "Identification of fungal DNA in BALF from patients with home-related hypersensitivity pneumonitis," Respiratory Medicine, vol. 105, no. 11, pp. 1696-1703, 2011.

[25] K. Hosoki, S. Iwamoto, T. Kumamoto, E. Azuma, and Y. Komada, "Early detection of breakthrough trichosporonosis by serum PCR in a cord blood transplant recipient being prophylactically treated with voriconazole," Journal of Pediatric Hematology/Oncology, vol. 30, no. 12, pp. 917-919, 2008.

[26] T. Sugita, M. Nakajima, R. Ikeda, Y. Niki, T. Matsushima, and T. Shinoda, "A nested PCR assay to detect DNA in sera for the diagnosis of deep-seated Trichosporonosis," Microbiology and Immunology, vol. 45, no. 2, pp. 143-148, 2001.

[27] M. Kumar, M. Mugunthan, R. Kapoor, and S. Pandalanghat, "Speciation of fungi using real time PCR with molecular beacons: Can we solve the enigma of diagnosis of invasive fungal disease?" Medical Journal Armed Forces India, vol. 75, no. 1, pp. 41-49, 2019.

[28] H. Makino, J. Fujimoto, and K. Watanabe, "Development and evaluation of a real-time quantitative PCR assay for detection and enumeration of yeasts of public health interest in dairy products," International Journal of Food Microbiology, vol. 140, no. 1, pp. 76-83, 2010.

[29] N. Mekha, T. Sugita, R. Ikeda, A. Nishikawa, and N. Poonwan, "Real-time PCR assay to detect DNA in sera for the diagnosis of deep-seated trichosporonosis," Microbiology and Immunology, vol. 51, no. 6, pp. 633-635, 2007. 


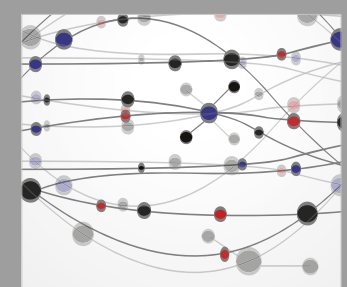

The Scientific World Journal
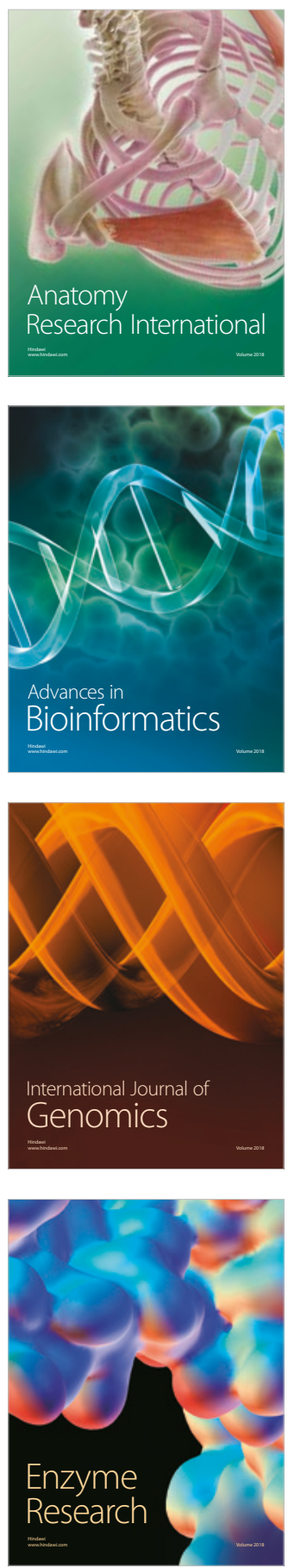
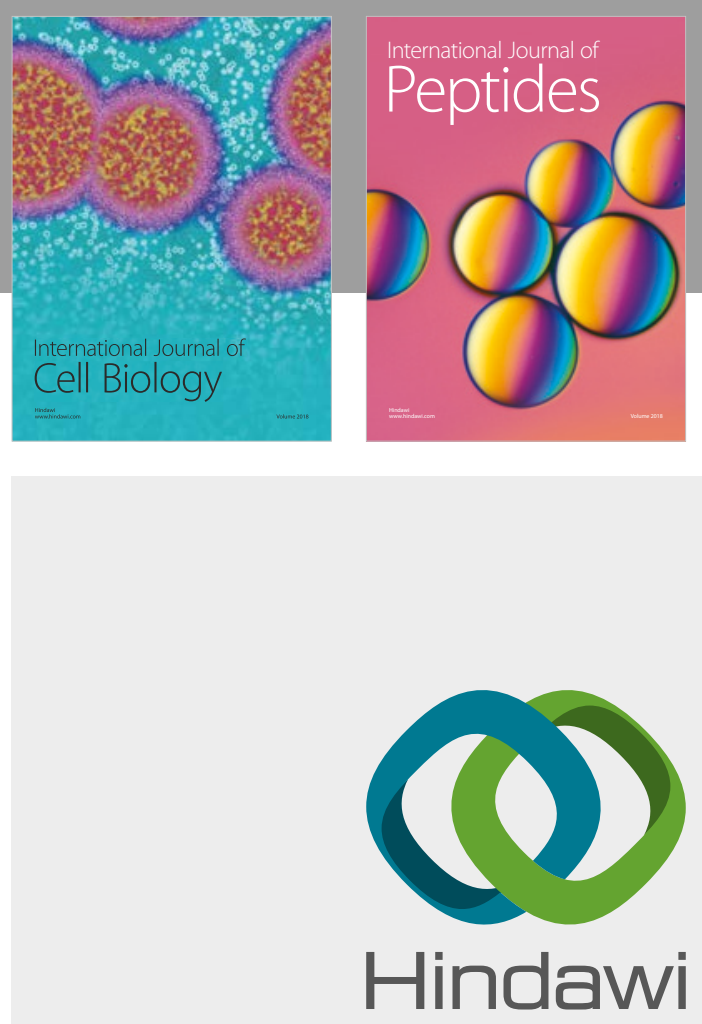

Submit your manuscripts at

www.hindawi.com
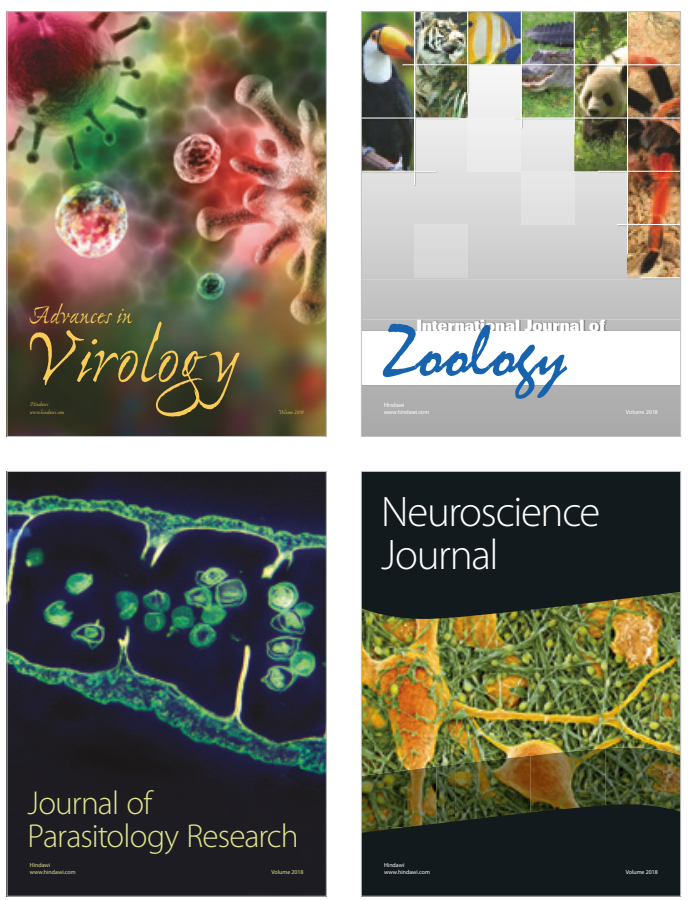
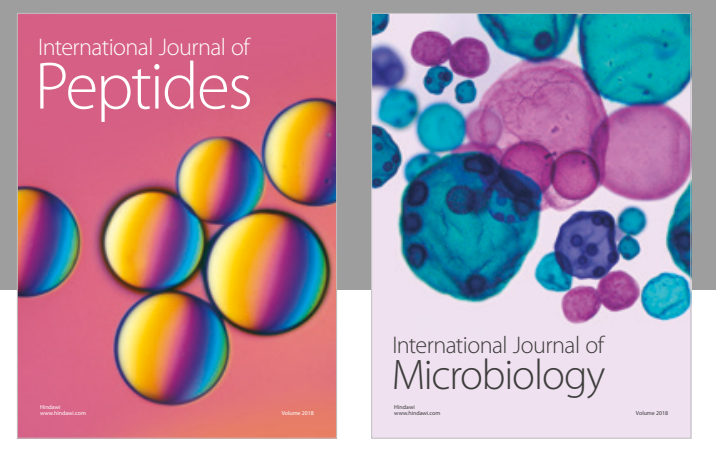

nternational Journal of Microbiology
Journal of
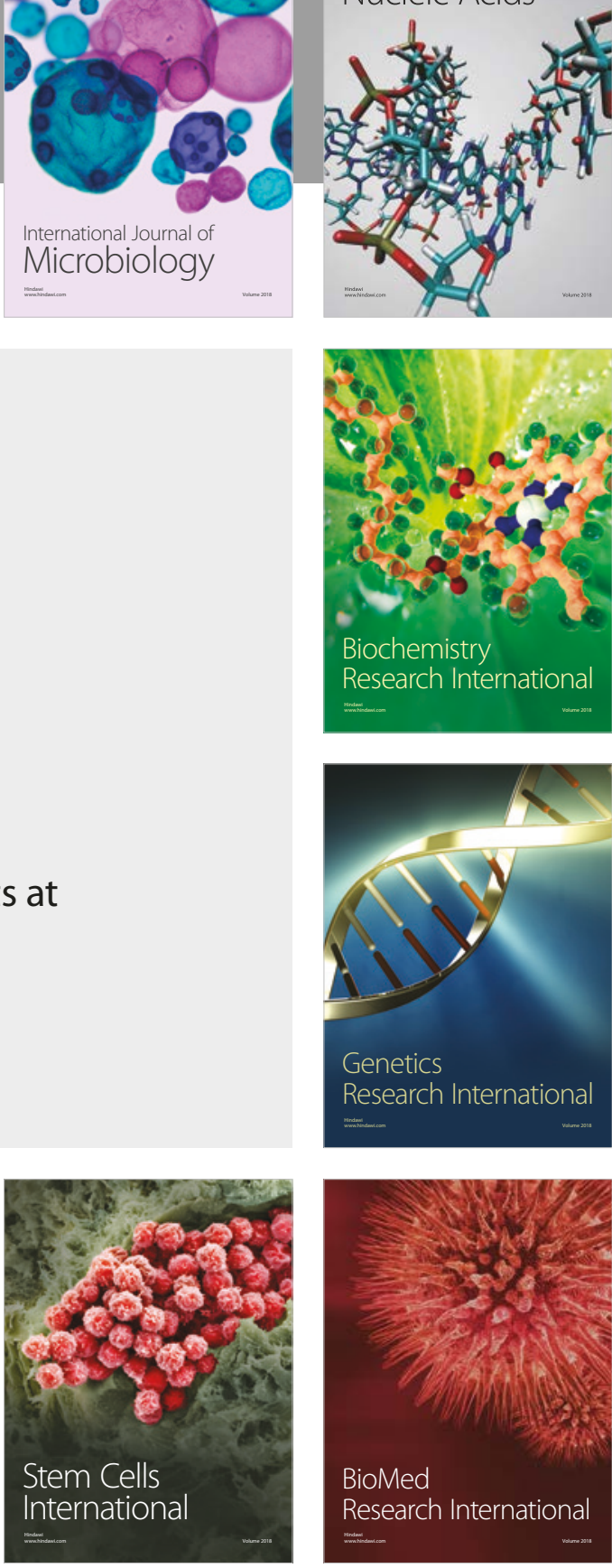
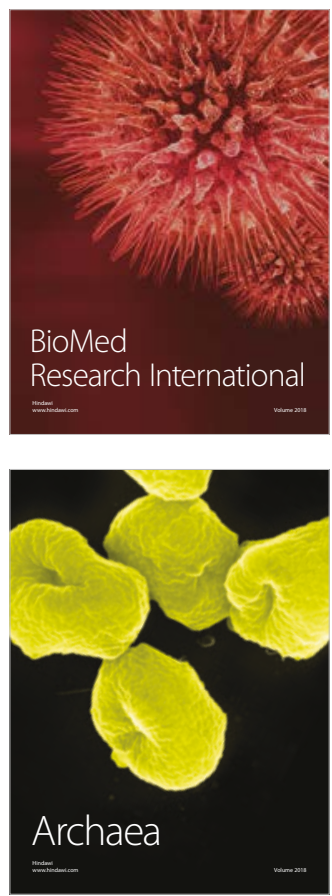